\title{
Historein
}

Vol 12 (2012)

Questions and Orientations in History during the last 20 years. Part 1

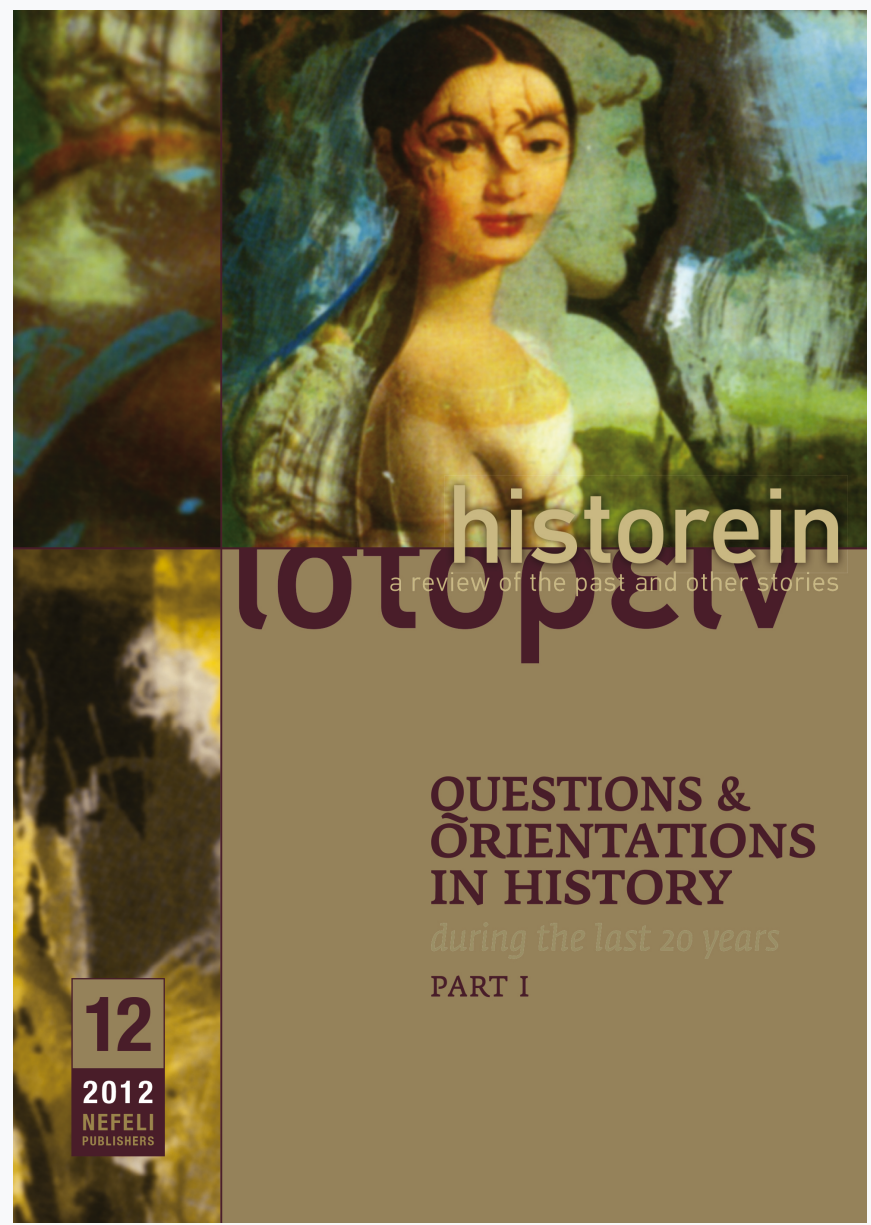

\section{From the Social History of the Reformation (1960-1980) to the Reformation as Communication Process (1990-2000)}

Costas Gaganakis

doi: $10.12681 /$ historein.157

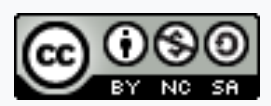

This work is licensed under a Creative Commons Attribution-NonCommercialShareAlike 4.0.

To cite this article:

Gaganakis, C. (2013). From the Social History of the Reformation (1960-1980) to the Reformation as Communication Process (1990-2000). Historein, 12, 79-91. https://doi.org/10.12681/historein.157 
I. Social history enters the scene, 1960s: The 'Moeller initiative'

Bernd Moeller's Reichsstadt und Reformation, published in 1962, has been widely acknowledged by historians of the Reformation as the pioneering work that paved the way for the invasion of social history of a field previously dominated by ecclesiastical and political historians.' Moeller was the first to focus on the question of the social appropriation of the Gospel; by calling on historians to direct their attention to the osmosis between Luther's ideas and urban sociopolitical realities, Moeller rid the historical community of a long-lasting interpretive tradition that has quite justifiably been depicted as "romantic idealism". 2

The "Moeller debate" that followed the publication of Reichsstadt und Reformation quickly revealed that his view of early modern urban sociopolitical and cultural realities underestimated the complexity of urban communities. Particularly, Moeller's assertion that Reformation ideals came into contact with late medieval civic communalism and contributed to its re-establishment in urban communities was rejected by the subsequent discussion, which concluded that there was no single and homogeneous conception of "civic communalism", precisely because of the differentiation of the urban audiences of the Reformation message. As shown by Thomas Brady in the case of Strasbourg, the Reformation was primarily conditioned by local realities and was not merely a chain reaction unleashed by the appearance of the reformer. Moeller's notion that "the civic society of Reformation Germany transformed Luther's gospel according to its own lights" has attained a consensus of opinion among social historians of the Reformation. ${ }^{3}$ But Moeller entirely missed

\section{From the Social} History of the Reformation
(1960-1980)

to the Reformation

as a Communication

Process (1990-2000)

\section{Costas Gaganakis}

University of Athens 
the point of his argument by failing to view the urban Reformation processes as the product of a dialectical relationship between the reform policies of urban authorities on the one hand and popular evangelical movements on the other, something vividly depicted by Bob Scribner in the case of Zwickau and Philip Broadhead in the case of Augsburg. ${ }^{4}$ On the other hand, Lorna Abray's study of Strasbourg during the Reformation has stressed the manipulation of evangelical preachers by civic oligarchies, who viewed the city preachers as "diffusion valves" for popular aspirations. Similar observations have led Scribner to suggest that urban preachers were the channels through which sociopolitical considerations shaped the original Reformation message. ${ }^{5}$

Furthermore, by insisting primarily on one medium of diffusion, the pamphlet, Moeller confined his study of urban reaction to the Reformation to the educated elite and ended up with a static and greatly idealised view of urban sociopolitical and cultural realities. Moeller approached the question of the contact of the Reformation with its urban audiences as one between a message spelled out from a unique source and a unified body of recipients. Miriam Chrisman and Bob Scribner have shown that neither was the "Protestant message" spelled out from a single source nor was it communicated in the same way to its urban audiences. The Reformation became a social movement because of the diversity of its dissemination to the masses. ${ }^{6}$

The discussion that ensued from the publication of the Moeller thesis has also shown that, at a broader, political level of investigation, he overestimated the ability of the German cities to implement their own policy of religious and ecclesiastical reform independently of external pressure. Thomas Brady's Turning Swiss has sufficiently underlined the limited political autonomy of imperial cities from princely political interests. Once the German Reformation crisis acquired a national dimension, urban Reformation processes gradually ceased to be exclusively "urban", as they had to conform to a pattern of ecclesiastical reform that did not necessarily correspond to their particular needs and aspirations. As H.C. Rublack put it, "urban Reformations cannot be understood as autogenously generating new ecclesiastical systems".?

\section{Social history triumphant, 1960s-1980s: The German Reformation as 'an urban event'}

The debate generated by Imperial Cities and the Reformation has highlighted the need for a multilevel approach to the Reformation; I propose to pinpoint three major interpretive approaches that emerged in the 1970s and 1980s, each of them focusing on a specific aspect of the Reformation as an urban event. These approaches should be viewed as working in close correlation, as they obviously constitute parts of the synthesis that has replaced the previous state of solitary investigations of the urban Reformation. All three will also serve to highlight the passage from social history to the new cultural history that has dominated the field since the early 1980s.

The first approach is primarily a sociopolitical but also a socioeconomic one, focusing mainly on the intersection of Reformation ideals with sociopolitical antagonisms and tensions in urban communities. The works of Christopher Friedrichs on class formation and social mobility in the early 
modern German city, Thomas Brady and Lorna Abray on Strasbourg, Bob Scribner on Leipzig and Zwickau, Heinz Schilling on the Hanseatic towns, Peter Blickle on Memmingen and Lyndal Roper and Philip Broadhead on Augsburg, reflected this particular approach and conversed critically with similar elaborations from a Marxist perspective, mainly pursued by East German social historiography in the late 1970s and early 1980s. ${ }^{8}$

Another feature of this approach was its preoccupation with the question of legitimacy regarding the appropriation of civic power by the governing oligarchies, which was contested by urban opposition groups. ${ }^{9}$ Blickle's stress on the far-ranging expectations that the Reformation generated with regards to the sociopolitical and economic conditions of the lower urban strata, the formulations of Abray and Scribner on the delicate position of urban evangelical preachers as social mediators and propagators of the new faith, Broadhead's presentation of the intricate debate that took place between lawyers and pastors in Reformation Augsburg, all attested to the potential antinomianism of the Reformation, in so far as it made people feel free of their obligations towards their rulers and the manmade laws that governed the life of the civic community.

As an example of the new spirit of criticism, Gerald Strauss points to the resistance to Roman law in Reformation Germany, stressing the heavy influence of religious considerations on peoples' "perceptions of legal constraints, and on the ways these constraints bound them to their political and social world", ${ }^{10}$ as the background to Luther's original call for a return to a purified form of Christianity. For Strauss, it was inevitable that, in the early days of the Reformation, "support for the evangelical case grew in large part out of the period's general dissatisfaction with existing legislation. Luther rallied his followers by holding out the prospect that the fall of the old order would bring new and better laws." This particular interpretation of Luther's early preaching exposed urban oligarchic regimes to the criticism of their citizen-subjects, first of all by removing their divine authority. As Hans-Christoph Rublack has argued, the tangible crisis of authority in the German urban regimes implied that "conflict rather than consent emerges as the hallmark of the Reformation"."

These considerations lead us to the second interpretive approach of the urban Reformation, one which could be called mainly political. The elaborations of Strauss and Broadhead on the contested legitimisation of the Reformation urban regimes, Schilling's study mentioned above, the works of John Stalnaker on Marburg, Scribner on Erfurt and, primarily, Brady's Turning Swiss sought to locate urban Reformation processes within the political framework of the empire by stressing the fundamental weakness of the urban front against the princes or the emperor. ${ }^{12}$ In all, as Mack Holt has recently remarked, these studies of the German urban Reformation showed that "the local social context and specific political situation mattered far more in determining the confessional outcome in any one city than any universal explanation could possibly provide". ${ }^{3}$

Besides these two interpretive approaches, some historians have focused on the urban mental and cultural universe and its interaction with the Reformation. This sociocultural approach rejected Moeller's oversimplified depiction of urban cultural realities in sixteenth-century Germany. From the relatively few contributions based on this approach in the historical production of the 1980s, the works of Miriam Chrisman and Bob Scribner stand out as the most thought-provoking examples. ${ }^{1 / 4}$ They underlined the varied pattern of dissemination of Protestantism in the German urban world; 
they pointed to the various media of dissemination and, equally, to levels of communication of the Reformation in the urban cultural milieu. They showed that the "Reformation message" was perceived differently by the elites, the commoners or the petty folk. Furthermore, Scribner pointed to the conscious appropriation of popular cultural themes - such as the "world turned upside down" - by the propagandists of the Reformation. ${ }^{15}$ Heavily imbued with the traits of new cultural history, these approaches to the Reformation were primarily concerned with "how the reform movement was perceived and expressed by its participants, how it interacted with the trends and tensions of the period, and how Protestant doctrine was translated into social and cultural reality". ${ }^{16}$

\section{The historiography of the French urban Reformation}

A similar pattern of methodological preferences and research orientations can be traced in the social historiography of the French Reformation of the 1970s and 1980s. Since the days of Henri Hauser and Lucien Febvre, the two rival poles in the historical interpretation of the Reformation, a debate has been taking place between advocates of a socioeconomic and political and, on the other hand, a mental-cultural causation of the French Reformation. The French urban communities have been the common field of investigation, as the French Reformation was equally described primarily as "an urban event"; in the early 1980s, new major works of synthesis and, especially, the challenging analysis of the changing fortunes of the French counterpart to the Reichstadt, the bonne ville by Bernard Chevalier, offered a more detailed view of the urban background to the advent of the Reformation. ${ }^{17}$ Interestingly enough, the French translation of Moeller's book did not seem to have any impact on the French historiography of the Reformation. ${ }^{18}$

The sociopolitical approach outlined in the case of the German Reformation movement seems to be equally prevalent in the social historiography of the French urban Reformation. A plethora of works has dealt with the sociopolitical rivalries that impeded the Protestant drive for supremacy in the urban communities of sixteenth-century France. Arlette Jouanna has shown the Huguenot camp of Montpellier to be bitterly divided, firstly within the elite - with merchants and bourgeois competing with the judiciary - and, secondly, between the elite and the lower citizen ranks. Denis Richet's study of the lists of Parisian Protestants slaughtered in the St Bartholomew's Day massacres revealed a long-standing antagonism between the officials of the sovereign court and the judicial clerks as a driving force behind the selective killings. Richard Gascon spoke of a Calvinist communal revolution in Lyon when describing the Protestant attempt to alter the balance of power to their advantage, whereas Philip Benedict, Mark Greengrass and Maryélise Suffern-Lamet stressed the limited possibilities of success for the dynamic Protestant minorities of Rouen, Toulouse and Caen, which they attributed to the lack of social space necessary for their expansion and eventual establishment. Finally, Henry Heller on Agen and Janine Garrisson on Midi also concluded that sociopolitical divisions between the "corps de ville" and the broader communes emerged as a stumbling block to the Calvinist takeover of the urban centres. ${ }^{19}$

Besides the above-mentioned historians, David Nicholls and Henry Heller also pointed to economic antagonisms that divided the Protestant camp into moderates and radicals. David Nicholls' study 
of the varied pattern of Protestant infiltration in Normandy and, mainly, Henry Heller's study of the popular evangelical movements of Meaux and Agen reveal that, on numerous occasions, the economic condition of the artisanat and of the lesser urban groups influenced their perception of the Reformation as a prospect of religious but, equally, social and economic change. ${ }^{20}$ The overall picture presented by the bulk of historical works based on the sociopolitical and -economic approach is, again, one of dissent as the hallmark of the urban Reformation.

As in the case of the German urban Reformation, a political interpretive approach became indispensable in the exploration of the French urban Reformation. The underlying theme of this approach has inevitably been that of the precarious relationship between king and city, central authority and urban autonomy. The studies of the urban evangelical movements of Montpellier, La Rochelle and Lyon by Jouanna, Jonathan Meyer and Gascon have put into relief the profound weakness of the Calvinist urban oligarchs in the face of a Catholic crown. ${ }^{21}$ As in Germany, the Calvinist urban ruling groups had to compromise between their drive for religious reform and the legality of their actions as official governing bodies bound to the monarch through bonds of respect and obedience.

Furthermore, Benedict, Peter France, Raymond A. Mentzer and Garrisson have pinpointed the role of regional Parlements as instruments of policy making and eventually political oppression. ${ }^{22}$ To match their enemy's strength, the Protestant communities had to seek the protection of the nobility, and the subordination of urban Protestant movements to the nobility appeared as the sole way of survival. Like the relevant studies on the political dimension of the German urban Reformation, research on the French case revealed a very fragile autonomy of urban Reformation processes from external pressures and manipulation. It warned historians against enclosing themselves in the confines of the urban microcosm if they truly aspired to an all-embracing interpretation of the Reformation crisis.

A third major interpretation of the French Reformation was the sociocultural. In an academic environment saturated with cultural anthropology and the mentalités, the trademark of the Annales' school, it was not surprising that the great majority of the French historians of the Reformation have sought to ascribe it to a mutation of the urban cultural and mental universe taking place over the longue durée. In the tradition of Lucien Febvre, cultural historians like Jean Delumeau traced the causation of the Reformation crisis in the collective psychology of late-medieval and early-modern Frenchmen. ${ }^{23}$ Others, like Bercé and Garrisson, have sought to explore the increasingly divided mental and cultural universe of the urban communities by pointing to the contrasting cultural manifestations of the petty folk and the urban elites. ${ }^{24}$ These investigations have shown that French Protestantism came into contact with divergent religious needs and cultural aspirations that were to impair its attempt to consolidate itself as a "collective organising myth", a religion of social cohesion. The contrasting patterns of the Reformation, the moderate, "introvert" stand of the notables and the radical and "extrovert" stand of the artisanat, attested to the subordination of Protestantism to the divisions of the French urban mental and cultural universe.

These considerations have prompted historians like Pierre Chaunu, Jean Delumeau and Roger Chartier to speak of Protestantism as a culmination of an acculturation process imposed by the urban elites on the petty folk. ${ }^{25}$ Taken to its extreme, this point of view has led to the notorious accul- 
turation thesis propounded by Robert Muchembled. ${ }^{26}$ The stress on the particular attraction to the Protestant message of the socially mobile, intellectually alert and technologically advanced socioprofessional groups in the French urban communities, put forward by Natalie Zemon Davis, Emmanuel Le Roy Ladurie and Philip Benedict, ${ }^{27}$ represented a more historicising approach, despite an occasional toying with neo-Weberianism, as particularly in the case of Ladurie's antithetical scheme "Huguenot carder-Catholic peasant". This has also echoed similar investigations into the social historiography of the German urban Reformation, mainly focused on the world of printers. ${ }^{28}$

The unprecedented crowd violence that emerged as the hallmark of the French wars of religion became the subject of a seminal article published by Davis in 1973. ${ }^{29}$ Her exploration of the semantics of religious violence subsequently triggered a series of studies which broadened impressively the field of investigation, focusing on Protestant iconoclasm as well as the renascent ideal of martyrdom in the service of the true faith, as claimed by both rival confessions in the religious wars of the Reformation. ${ }^{30}$ More importantly, this investigation of patterns of violent crowd behaviour and especially of religious rioting in the French Reformation crisis heralded in many ways a major shift of historians' attention from the "core subjects" of social history - that is the study of social structures, patterns of social organisation and social behaviour - to the study of representations and symbolic systems; a shift from social history to the research orientations, methodologies and conceptual tools of new cultural history, which would come to dominate the broader historiographical field by the mid-1980s. Davis' interpretive approach was taken much further with the publication of Denis Crouzet's seminal Les guerriers de Dieu in 1990. Crouzet questioned the predominant socioeconomic and sociopolitical interpretations of the French Reformation crisis, by placing emphasis on a mental climate of acute eschatological agony, which he saw as the background to the escalation of religious violence in the French wars of religion. With his stress on the "prophetic vision globally animating Catholic society" in a total war against the heretics, and his description of the Calvinist teachings on predestination as a reaction to the eschatological agony of the days, Crouzet has been hailed by some historians - and criticised by others - for "bringing back religion" to the historiography of the Reformation. ${ }^{31}$

\section{The social historiography of the urban Reformation in Germany and France, 1980s-2000s: The social appropriation of the Gospel and the Reformation as a communication process}

In the three decades that followed the Moeller debate, social historians of the urban Reformation have gained an impressively richer view of the multileveled political, socioeconomic and cultural realities that constituted the background to the original contact of the Reformation with the urban world. Historians have also acknowledged the limitations of their preoccupation with the urban manifestations of the Reformation crisis. Among other things, social historians of the German urban Reformation realised that they should not concentrate solely on the larger urban communities, such as the imperial cities. A multiplicity of lesser towns, like the territorial and periphery towns of approximately 500-1,500 inhabitants, should also be taken into consideration, as they constituted the majority in the early modern German urban world. The investigation of the Ref- 
ormation processes in these towns would further illuminate the limits of the "urban" character of the Reformation. ${ }^{32}$

Informed by the conceptual tools offered by social and cultural anthropology for the interpretation of religious practices, rituals and the investigation of collective representations, and, to a lesser degree, by the research orientations put forward by Marxist historiography, namely the stress on the inner divisions of the evangelical movements and the interaction of the Lutheran message with socioeconomic realities, social historical studies of the urban Reformation in Germany "truly exploded". ${ }^{33}$ The question of the social appropriation of the Gospel, introduced by Moeller's work, remained central in these subsequent investigations, which were concerned with "how the reform movement was perceived and expressed by its participants, how it interacted with the trends and tensions of the period and how protestant doctrine was translated into social and cultural reality". ${ }^{34}$ Moreover, the dynamic entrance of feminist studies into the field has highlighted the gender dimension of the Reformation, making historians realise that the various contrasting appropriations of the evangelical message, as well as the various reconstructions of urban communities (both symbolic and material), were coloured by the aspirations and phobias of an institutional majority, with the male artisan world emerging as the principal promoter of the reformed message. ${ }^{35}$

Lastly, a new major field of investigation in the social and cultural history of the Reformation in the last two decades, stemming primarily from Bob Scribner's pioneering publications on the propaganda strategies and media of dissemination of the German Reformation, has promoted one particularly important aspect of the Reformation, as a communication process. ${ }^{36} \mathrm{New}$ cultural historians have focused on the various media of dissemination and propaganda strategies adopted by both rival confessional camps in the "war of words" that was unleashed with the massive appearance of Lutheran ideas through print. In their investigation of the contact of the relatively new medium of print with the predominantly oral culture of sixteenth-century Europe, historians have borrowed conceptual tools and methods from the history of reading, one particularly dynamic genre incorporated into the new cultural history and propounded principally from the French historian Chartier, ${ }^{37}$ as well as from an excellent tradition of bibliographical essays, with Jean François Gilmont and Francis Higman as the main representatives.$^{38}$

This novel approach has combined studies of the propaganda war between Luther, Calvin and other leading reformers and their Catholic opponents with parallel investigations of the interaction of the various "evangelical messages" with the social and cultural universe of their target groups, their intended "readers' communities". ${ }^{39}$ The "war of words and images" of the Reformation was now investigated in correlation with the predominant orality of early modern European society. Studying this interaction, historians have stressed that the printed discourse did not emerge as the revolutionary novel medium that dismantled traditional perceptions and ways of envisaging and of confronting reality; on the contrary, it subjected itself to the practices of the prevalent oral culture.

The printed propaganda of both sides drew extensively on rhetorical strategies inherent in oral and visual means of communication and confrontation. In an effort to infiltrate society and to shape a "public opinion" that would homogenise its cultural multiformity, printed propaganda discourse used different strategies to attract different audiences and readers' groups; it "spoke a different 
language" and generated different emotions to different people. Print and other oral forms of communication often became fused in new, hybrid forms of media. Moreover, research has shown that both Protestant and Catholic printed propaganda were not "immune" to their encompassing cultural milieux. The multiplicity of propaganda discourses, the breadth of their thematology, their expressive media and their dynamics appealed to - and were influenced by - the multiple expectations of early modern society. $4^{0}$ This particular interpretive approach of the Reformation as a "communication process" (or "revolution in communication") has recently expanded into the new and rising field of the history of emotions. In her stimulating The Reformation of Feeling, Susan Karant-Nunn offers a penetrating look at the experience of emotions in both Protestant and Catholic cultures, highlighting the ways in which new religious norms for emotional comportment ("emotional management") were intertwined with programmes for social discipline in the Protestant and Tridentine communities. ${ }^{41}$

The establishment of new cultural history as the dominant interpretative trend in Reformation historiography since the mid-1980s has added new subject matters and, primarily, has introduced a new interdisciplinarity among historians, privileging new thematic fields of collective investigation, such as the history of emotions briefly discussed above. Nowadays, based on accumulated experience from the field, as well as on historical reflexivity, we can claim that this shift does not necessarily entail the eclipse of "traditional subject matters" of social history, namely social explanation and social causality. ${ }^{42}$ In the introduction to his recent major synthesis, Christ's Churches Purely Reformed: A Social History of Calvinism, Philip Benedict reminded historians of some basic facts regarding the history of the Reformation:

The Reformed tradition offered a new interpretation of Christianity's sacred texts. Inevitably, its emergence affected the other power networks in society, just as its articulation and institutionalisation took place within constraints set by these networks ... No account of the subsequent unfolding of the tradition can neglect the interplay across successive generations between the force of religious imperatives, the conditioning influence of other power networks, and the play of contingent events. Beliefs make history, but not under circumstances of their choosing. They are also themselves the products of history.

Benedict continued: "The interplay between the force of religious tradition and the contexts in which it arose and took roots lies at the heart" of the sociocultural approach of the Reformation. ${ }^{43}$

\section{NOTES}

1 Bernd Moeller, Imperial Cities and the Reformation: Three Essays, Philadelphia: Fortress Press, 1972; Idem, Villes d'Empire et Reformation, Geneva: Droz, 1966; A.G. Dickens and John M. Tonkin, The Reformation in Historical Thought, Oxford: Blackwell, 1985, 298-300; Hans Christoph Rublack, "Is there a 'New History' of the urban Reformation?", in Tom Scott and Erkki Kouri (eds), Politics and Society in Reformation Europe, Basingstoke: Macmillan, 1987, 125-131; Thomas Brady, "'The Social History of 
the Reformation': Between 'Romantic Idealism' and 'Sociologism': A Reply”, in Wolfgang J. Mommsen, Peter Alter and Robert W. Scribner (eds), The Urban Classes, the Nobility and the Reformation: Studies in the Social History of the Reformation in England and Germany, Stuttgart: Klett Cotta, 1979, 42-43; Steven Ozment, The Reformation in the Cities: The Appeal of Protestantism to Sixteenth Century Germany and Switzerland, New Haven: Yale UP, 1975, 6-9; Robert W. Scribner, The German Reformation, Houndmills: Macmillan, 1986, 1-2. For an extensive review of the "Moeller initiative" and the debate it generated among social historians, see Erik Midelfort, "Toward a Social History of Ideas in the German Reformation", in Kyle Sessions and Philip Bebb (eds), Pietas et Societas: New Trends in Reformation Social History, Kirksville: Sixteenth Century Journal, 1985.

2 Roughly speaking, this has been the view that interpreted the Reformation crisis as the culmination and major manifestation of the "eternal Reformation principle" in the specific time, place and personality that were the sixteenth century, Germany and Martin Luther. With its excessive stress on Luther as the protagonist of the drama, the quasi-prophetic figure that was endowed with the will and the charisma to restore purity in the Christian faith, this view was indeed a Luther cult, as its entire argumentation and conceptual framework were drawn from theology rather than history. See Brady, "The Social History of the Reformation", 41-42.

3 lbid., 43.

4 R.W. Scribner, "The Reformation as a Social Movement", in Mommsen, Alter and Scribner (eds), The Urban Classes, 53-63; Philip Broadhead, "Politics and Expediency in the Augsburg Reformation", in Peter Brooks (ed.), Reformation Principle and Practice: Essays in Honour of A. G. Dickens, London: Scolar Press, 1980, 55-70; Rublack, "Is there a 'New History' of the Urban Reformation?", 125.

5 Lorna Abray, The People's Reformation: Magistrates, Clergy and Commons in Strasbourg, 1500-1598, Ithaca: Cornell UP, 1985; R.W. Scribner, "Practice and principle in the German towns: Preachers and people", in Brooks (ed.), Reformation Principle and Practice, 97-117; Idem, "Memorandum on the Appointment of a Preacher in Speyer, 1538", Bulletin of the Institute of Historical Research 48 (1975): 248-253.

6 Miriam Chrisman, Lay Culture, Learned Culture: Books and Social Change in Strasbourg, 1480-1599, New Haven: Yale UP, 1982. See also her Conflicting Visions of Reform: German Lay Propaganda Pamphlets, 1519-1530, Atlantic Highlands: Humanities Press, 1995. Scribner, "The Reformation as a Social Movement".

7 Thomas Brady, Turning Swiss: Cities and Empire, 1450-1550, CUP, 1985; Rublack, "Is there a 'New History' of the urban Reformation?", 130.

8 Christopher Friedrichs, "Capitalism, Mobility and Class Formation in the Early Modern German City", Past and Present 69 (1975): 24-49. Besides the works by Brady, Scribner and Abray cited above, see also Lyndal Roper, The Holy Household: Women and Morals in Reformation Augsburg, Oxford: Clarendon Press, 1991, and Thomas A. Brady, "Patricians, Nobles, Merchants: Internal Tensions and Solidarities in South German Ruling Classes at the Close of the Middle Ages", in Myriam U. Chrisman and Otto Grundler (eds), Social Groups and Religious Ideas in the Sixteenth Century, Kalamazoo: Medieval Institute of Western Michigan University, 1978; Idem, "In Search of the Godly City: The Domestication of Religion in the German Urban Reformation", in Ronnie Po-Chia Hsia (ed.), The German People and the Reformation, Ithaca: Cornell UP, 1988, 16-31. Peter Blickle, The Revolution of 1525: The German Peasants' War from a New Perspective, Baltimore: Johns Hopkins UP, 1981, also Idem, "Social Protest and Reformation Theology", in Kaspar von Greyerz (ed.), Religion, Politics and Social Protest: Three Studies on Early Modern Germany, London: Allen \& Unwin, 1984; Heinz Schilling, "The Reformation in the Hanseatic Cities", Sixteenth Century Journal 14 (1983): 443-456; H.C. Rublack, "Martin Luther and the Urban Social Experience", Sixteenth Century Journal 16/1 (1985): 15-32. For a valuable contribution 
coming from a Marxist perspective, see Karl Czok, "The Socio-economic Structure and Political Role of the Suburbs in Saxony and Thuringia in the Age of the German Early Bourgeois Revolution", in R.W. Scribner and Gerhard Benecke (eds), The German Peasant War of 1525: New Viewpoints, London: Allen \& Unwin, 1979. Also, Günther Vogler, "Imperial City Nuremberg, 1524-1525: The Reform Movement in Transition", in Hsia (ed.), The German People and the Reformation, 36-45.

9 This was the main point raised in Christopher R. Friedrichs, "Citizens or Subjects? Urban Conflict in Early Modern Germany", in Chrisman and Grundler (eds), Social Groups and Religious Ideas.

10 Gerald Strauss, Law, Resistance and the State: The Opposition to Roman Law in Reformation Germany, Princeton: Princeton UP, 1986, 199.

11 Ibid., 192, 208. Rublack, “Is there a 'New History' of the Urban Reformation?”, 132.

12 John Stalnaker, "Residenzstadt and Reformation: Religion, Politics and Social Policy in Hesse, 15091546”, Archiv für Reformationsgeschichte 64 (1973): 113-146; R.W. Scribner, “Civic Unity and the Reformation in Erfurt", Past and Present 66 (1975): 29-60; Gerald Strauss, Nuremberg in the Sixteenth Century: City Politics and Life between Middle Ages and Modern Times, Bloomington: Indiana UP, 1976.

13 Mack P. Holt, "The Social History of the Reformation: Recent Trends and Future Agendas", Journal of Social History 37/1 (2003): 133-144, see esp. 134-135.

14 Steven Ozment's The Reformation in the Cities: The Appeal of Protestantism to Sixteenth Century Germany and Switzerland, New Haven: Yale UP, 1975, could be an obvious third point of reference; yet, his over-simplistic depiction of the "liberating effect" of the contact of early Protestantism with the urban social groups ultimately follows the argumentation of Moeller, whom the American historian accuses of sociologism.

15 In his ground-breaking For the Sake of Simple Folk: Popular Propaganda for the German Reformation, 2nd ed., Oxford: Clarendon, 1994, 1-9, 148-189.

16 C. Scott Dixon (ed.), The German Reformation: The Essential Readings, Oxford: Blackwell, 1999, 3.

17 Bernard Chevalier, Les Bonnes Villes de France du XIVe au XVIe siècle, Paris: Aubier Montaigne, 1982; Georges Duby (ed.), Histoire de la France urbaine: vol. 3; La ville classique, Paris: Seuil, 1981.

18 For a concise review of the evolution of the historiography of the Reformation in France in the 1970s and 1980s, see David Nicholls, "The Social History of the French Reformation: Ideology, Confession and Culture", Social History 9/1 (1984): 25-43; Mark Konnert, "Urban values versus religious passion: Châlons-Sur-Marne during the Wars of Religion", Sixteenth Century Journal $23 / 3$ (1989): 387-405, esp. 388-390; for a more recent perspective, Nicolette Mout, "Reformation, Revolt and Civil Wars: The Historiographic Traditions of France and the Netherlands", in Philip Benedict et al. (eds), Reformation, Revolt and Civil War in France and the Netherlands, 1555-1585, Amsterdam: Royal Netherlands Academy of Arts and Sciences, 1999, 24-31; Holt, "The Social History of the Reformation", 134-135.

19 Arlette Jouanna, “La prise du pouvoir urbain par les Reformés à Montpellier, 1561-1563”, in Bernard Chevalier and Robert Sauzet (eds), Les Réformes: Enracinements Socio-culturels, Paris: Editions de la Maisnie, 1985, 151-160; Denis Richet, "Aspects socio-culturels des conflits religieux à Paris dans la seconde moitié du XVI siècle", Annales ESC 32/4 (1977): 764-789; Richard Gascon, Grand Commerce et Vie Urbaine au XVle siècle: Lyon et ses Marchands, Paris: Mouton, 1971; Philip Benedict, Rouen during the Wars of Religion, Cambridge: Cambridge UP, 1981; Mark Greengrass, "The Anatomy of a Religious Riot in Toulouse in May 1562”, Journal of Ecclesiastical History 34/3 (1983): 367-391; Maryélise Suffern-Lamet, “French Protestants in a Position of Strength: The Early Years of the Reformation in Caen, 1558-1568", Sixteenth Century Journal 9/3 (1978): 35-55; Henry Heller, The Conquest of Poverty: The Calvinist Revolt in Sixteenth-Century France, Leiden: E.J. Brill, 1986; Janine Garrisson, Protestants du Midi, Toulouse: Privat, 1980. 
20 David Nicholls, "Social Change and Early Protestantism in France: Normandy, 1520-1562", European Studies Review 10 (1980): 279-308; Henry Heller, “Famine, Revolt and Heresy at Meaux, 1521-1525", Archiv für Reformationsgeschichte 68 (1977): 133-157, a thesis further elaborated in his challenging The Conquest of Poverty.

21 Jonathan Meyer, "La Rochelle and the Failure of the French Reformation", Sixteenth Century Journal 15/2 (1984): 169-183.

22 Peter France, “Les protestants à Grenoble au XVle siècle”, Cahiers d'Histoire 3 (1962): 319-331; Raymond Mentzer, "Calvinist propaganda and the Parlement of Toulouse", Archiv für Reformationsgeschichte 68 (1977): 268-283.

23 Jean Delumeau, Naissance et affirmation de la Réforme, Paris: PUF, 1965.

24 Yves Marie Bercé, Revolt and Revolution in Early Modern Europe, Manchester: Manchester UP, 1987, and Idem, Fête et Révolte. Des mentalités populaires du XVIe au XVIIle siècle, Paris: Hachette, 1976.

25 Pierre Chaunu, “Niveaux de culture et Réforme”, Bulletin de la Société de l'Histoire du Protestantisme français 118 (1972): 305-325; Roger Chartier, "Culture as Appropriation: Popular Cultural Uses in Early Modern France", in Steven L. Kaplan (ed.), Understanding Popular Culture: Europe from the Middle Ages to the Nineteenth Century, New York: Mouton, (1984), 229-253.

26 Robert Muchembled, Culture populaire et culture des élites dans la France moderne, XVe-XVIIle siècles, Paris: Flammarion, 1978; Nicholls, “The Social History of the French Reformation”, 43. For a critique of the acculturation thesis, see Jean Wirth, "Against the Acculturation Thesis", in Kaspar von Greyerz (ed.), Religion and Society in Early Modern Europe, 1500-1800, Boston: Allen \& Unwin, 1984, 67-77; R.W. Scribner, "Popular Politics and Cultural Conflict in Early Modern Europe", European History Quarterly 18/1 (1988): 71-74.

27 Natalie Zemon Davis, “Strikes and Salvation at Lyon”, Archiv für Reformationsgeschichte 56 (1965): 4864; Emmanuel Le Roy Ladurie, The Peasants of Languedoc, Urbana: University of Illinois Press, 1974; Benedict, Rouen during the Wars of Religion, 71-93.

28 Richard Cole, "Reformation printers: Unsung Heroes", Sixteenth Century Journal 15/3 (1984): 327-339.

29 Natalie Zemon Davis, "The Rites of Violence: Religious Riot in Sixteenth-Century France", Past and Present 59 (1973): 51-91, reprinted in her Society and Culture in Early Modern France, Cambridge: Polity Press, 1987, 152-187.

30 Solange Deyon and Alain Lottin, Les casseurs de l'été 1566: L'iconoclasme dans le Nord, Lille: Presses Universitaires de Lille/Westhoek, 1986; Carlos M.N. Eire, War Against the Idols: The Reformation of Worship from Erasmus to Calvin, Cambridge: Cambridge UP, 1989; Olivier Christin, Une révolution symbolique: L'iconoclasme huguenot et la reconstruction catholique, Paris: Editions de Minuit, 1991; David El Kenz, Les Bûchers du Roi: La culture protestante des martyrs (1523-1572), Seyssel: Champ Vallon, 1997; Susan Karant-Nunn, Reformation of Ritual: Interpretation of Early Modern Germany, London: Routledge, 1997; Lee Palmer Wandel, Voracious Idols and Violent Hands: Iconoclasm in Reformation Zurich, Strasbourg and Basel, Cambridge: Cambridge UP, 1999; Frank Lestringant, Lumière des martyrs: Essai sur le martyre au siècle des Réformes, Paris: Honoré Champion, 2004.

31 Denis Crouzet, Les Guerriers de Dieu: La violence au temps des troubles de religion, vers 1525-vers 1610, 2 vols, Seyssel: Champ Vallon, 1990. For an insightful review, see Mark Greengrass, "The Psychology of Religious Violence", French History 5/4 (1991): 467-474.

32 A.G. Dickens had called for the historians' attention on that particular aspect of the early Reformation in his The German Nation and Martin Luther, London: Edward Arnold, 1974, 177-178. See, among others, Tom Scott, Freiburg and the Breisgau: Town-Country Relations in the Age of the Reformation and 
Peasants' War, Oxford: Clarendon Press, 1987; C. Scott Dixon, The Reformation and Rural Society: The Parishes of Brandenburg-Ansbach-Kulmbach, 1528-1603, Cambridge: Cambridge UP, 1995.

33 Ronnie Po-Chia Hsia, "Introduction”, in Idem (ed.), The German People and the Reformation, 2-7; Holt, "The Social History of the Reformation", 134-135. Besides the works cited by Holt in footnote 13, see also, Johannes C. Wolfart, Religion, Government and Political Culture in Early Modern Germany: Lindau, 1520-1628, Basingstoke: Macmillan, 2001.

34 See the introduction in C. Scott Dixon (ed), The German Reformation: The Essential Readings, Oxford: Blackwell, 1999, 3,

35 I cite as an example Lyndal Roper's pioneering article, “The ‘Common Man', 'Common Good', 'Common Women': Gender and Meaning in the German Reformation”, Social History 12/1 (1987): 1-21.

36 Scribner, For the Sake of Simple Folk, also, Idem, "The Image of the Reformation", in Jim Obelkevich, Lyndal Roper and Raphael Samuel (eds), Disciplines of Faith: Studies in Religion, Politics and Patriarchy, London: Routledge and Kegan Paul, 1987; Idem, "Heterodoxy, Literacy and Print in the Early German Reformation", in Peter Biller \& Anne Hudson (eds), Heresy and Literacy, 1000-1530, Cambridge: Cambridge UP, 1996. Elizabeth Eisenstein's The Printing Revolution in Early Modern Europe, Cambridge: Cambridge UP, 1983 was another major source of inspiration; yet it was primarily Bob Scribner and Richard Cole who focused on the interaction of printed media with other forms of, predominantly oral, communication. Richard G. Cole, "Pamphlet Woodcuts in the Communication Process of Reformation Germany", in Sessions and Bebb (eds), Pietas and Societas, 103-121.

37 Roger Chartier, The Cultural Uses of Print in Early Modern France, Princeton: Princeton UP, 1987; The Culture of Print: Power and the Uses of Print in Early Modern Europe, Cambridge: Polity Press, 1989; The Order of Books: Readers, Authors, and Libraries in Europe between the Fourteenth and Eighteenth Centuries, Cambridge: Polity Press, 1994.

38 Jean François Gilmont, Jean Crespin, un éditeur réformé du XVle siècle, Geneva: Droz, 1981; Idem, Jean Calvin et Le Livre Imprimé, Geneva: Droz, 1997; Idem, La Réforme et le livre. L'Europe et l'imprimé (1517-v. 1570), Paris: Les Editions du Cerf, 1990. Francis Higman, Lire et Découvrir: La circulation des idées au temps de la Réforme, Geneva: Droz, 1998; Denis Pallier, Recherches sur l'imprimerie à Paris pendant la Ligue (1585-1594), Geneva: Droz, 1975.

39 Gabrielle Berthoud (ed.), Aspects de la Propagande Religieuse, Geneva: Droz, 1957; Gilbert Schrenck, "Jeu et théorie du pamphlet dans le Journal du règne de Henri III (1574-1589) de Pierre de l'Estoile", Traditions Polémiques, Paris: École normale supérieure de jeunes filles, 1984, 69-79; Helga Robinson-Hammerstein (ed), The Transmission of Ideas in the Lutheran Reformation, Dublin: Irish Academic Press, 1989; Keith Moxey, Peasants, Warriors, and Wives: Popular Imagery in the Reformation, Chicago: University of Chicago Press, 1989; David Bagchi, Luther's Earliest Opponents: Catholic Controversialists, 1518-1525, Minneapolis: Fortress Press, 1991; Erika Rummel, Scheming Papists and Lutheran Fools: Five Reformation Satires, New York: Fordham UP, 1993; Peter Biller and Anne Hudson (eds), Heresy and Literacy, 1000-1530, Cambridge: Cambridge UP, 1994; Mark U. Edwards Jr, Printing, Propaganda and Martin Luther, Berkeley: University of California Press, 1994; Robin Barnes, Robert Kolb, Paula Presley et al. (eds), Books Have their Own Destiny, Kirksville: Thomas Jefferson University Press, 1998; Peter Matheson, The Rhetoric of the Reformation, Edinburgh: T\&T. Clark, 1998; Luc Racaut, Hatred in Print: Catholic Propaganda and Protestant Identity during the French Wars of Religion, Aldershot: Ashgate, 2002; Charles Postel, Traité des Invectives au Temps de la Réforme, Paris: Les Belles Lettres, 2004; Andrew Pettegree, Reformation and the Culture of Persuasion, Cambridge: Cambridge UP, 2005.

40 For similar considerations, see Ulinka Rublack, Reformation Europe, Cambridge: Cambridge UP, 2005, $10-11$. 
41 Susan Karant-Nunn, The Reformation of Feeling: Shaping the Religious Emotions in Early Modern Germany, Oxford UP, 2010.

42 As suggested by Geoff Eley's A Crooked Line: From Cultural History to the History of Society, Ann Arbor: University of Michigan Press, 2005, 183-186.

43 Philip Benedict, Christ's Churches Purely Reformed: A Social History of Calvinism, New Haven: Yale University Press, 2002, xxii. 